\title{
Training Transfer: Does Training Design Preserve Training Memory?
}

\author{
Saeed Khalifa Alshaali ${ }^{1}$, Kamal Ab Hamid ${ }^{2}$ \& Ali Ali Al-Ansi ${ }^{3,4}$ \\ ${ }^{1}$ School of Business Management, College of Business, University Utara Malaysia, Malaysia \\ ${ }^{2}$ School of Accountancy, College of Business, University Utara Malaysia, Malaysia \\ ${ }^{3}$ Tunku Puteri Intan Safinaz, School of Accountancy, College of Business, University Utara Malaysia, Malaysia \\ ${ }^{4}$ College of Business Administration, Shaqra University, Kingdom of Saudi Arabia \\ Correspondence: Saeed Khalifa Alshaali. E-mail: skalshal@gmail.com
}

\author{
Received: August 11, $2018 \quad$ Accepted: August 25, $2018 \quad$ Online Published: September 28, 2018 \\ doi:10.5539/ass.v14n10p46 URL: https://doi.org/10.5539/ass.v14n10p46
}

\begin{abstract}
Billions of dollars are lost by low application of ineffective training. Fast declination of training memory may contribute this loss. The present study uses theoretical examinations via a conceptual model to examine the relationship between training memory and transfer behaviour. Training design, training retention (training memory), and training transfer are the study variables. The study population, is the federal ministries in the United Arab Emirates (UAE), was assessed via random sampling. Data were collected by a cross-sectional approach via questionnaires. Back-translation (English to Arabic), a pre-test, and a pilot test were applied to ensure that any modifications of the questionnaire items were precise and effective. The study was analysed via PLS-SEM. Based on the results, all of the study's hypotheses were accepted, and significant relationships were revealed between the study variables. Training design is highly correlated with training retention, i.e., a premium training design will lead to a high preservation of the knowledge and skills gained from the training programme. Due to the low correlation between training retention and training transfer, the training retention was considered a secondary contributor of applying training to the work environment. If mangers and practitioners tend to achieve successful training transfer, their efforts should concentrate on adopting modern training design techniques, which could sufficiently maintain the training memory and increase training transfer.
\end{abstract}

Keywords: training transfer, training design, training retention, memory, training techniques and instrumental methods

\section{Introduction}

Training transfer, or applying training on the job, is a global concern in human resources management (Baldwin $\&$ Ford, 1988). Accordingly, training transfer has garnered considerable attention from researchers and training professionals (Bhatti, Kaur, \& Battour, 2013). In other words, this transfer has become a key criterion for evaluating the effectiveness of training programmes (Baldwin \& Ford, 1988).

Due to the low number of applications (transfer) and the high expenditures of training at work, many scholars began theorizing about this phenomenon to understand the transfer complex process (Baldwin \& Ford, 1988; Holton, 1996, 2005; Kavanagh, 1998; Tracey, Tannenbaum, \& Kavanagh, 1995). For instance, Baldwin and Ford (1988) and Holton, Bates, and Ruona (2000) established the most common models of training transfer in the pursuit of a holistic understanding of the transfer process. This study considered those efforts valuable contributions toward theorizing training transfer and therefore the present study aims to examine a new conceptual model consisting of three variables (training design, training retention (mediator), and training transfer; dependent variables) with detailed justifications of the relationship between training design and training retention (training memory). Accordingly, several hypotheses are suggested for the study's conceptual model.

Another important contribution of the present study is that it is applied in the governmental sector. In general, transfer studies have rarely focused on the public sector (McCracken, Brown, \& O'Kane, 2012). In detail, what is remarkable about this study is the broad description and review of the relationship between training design and training retention. Furthermore, this study draws a new logical (practical) diagram that explains how training design could preserve training memory with the consideration of time. Therefore, this study recalled several physiological theories to add significant value to its argument. Subsequently, this review raised the 
understanding of how, practically and rationally, training design could affect training retention. In this study, whenever the term "retention" is mentioned, it represents the term "memory" and vice versa.

\section{The Practical Consequences of Transfer and Memory Loss}

The weekly applications of training on the job (effectiveness), as well as the high training expenditure (efficiency), are the main tangible and practical problems of training transfer. Despite the considerable expenditures on training worldwide (USA - 1982, UK - 2010, and Germany - 2010 annually spend as much as $\$ 100$ billion, $£ 38.6$ billion, and 28.6 billion euros, respectively), only $10 \%-27 \%$ of training programmes are applied to the job (Arthur, Bennett, Edens, \& Bell, 2003; CIPD, 2015; Ford, 2009; Georgenson, 1982; Griffin, 2010; Industry Report, 2000).

In addition to the problem of the low transfer rate and the significant expenditures for training, the high rates of participants' forgetting the knowledge and skills learned from the training programme are also challenging. Generally, it is known that all kinds of learned knowledge and skills are typically forgotten, either gradually or rapidly, after the learning activity (Custers, 2010; Jaber \& Sikström, 2004; Mozer \& Lindsey, 2016; Ritter, Baxter, Kim, \& Srinivasmurthy, 2011); Ritter et al. (2011) described the high forgetting rate of trained skills as a dangerous phenomenon. Other researchers have estimated that approximately $40 \%$ of training content is usually transferred immediately after training, $25 \%$ is retained after six months, and only $10-15 \%$ is retained after one year (Baldwin \& Ford, 1988; Wexley \& Latham, 2002). Furthermore, Ebbinghaus (1964), the innovator of the "Forgotten curve", proved that more than $33 \%$ and $21 \%$ of the newly-learned information is retained for only one day and one month, respectively.

\section{Theoretical Foundation}

The reliance on a theoretical foundation serves to help the researcher to test or contribute to the existing literature or to explain and understand the interactional factors in a specific domain (Bryman \& Bell, 2011; Creswell, 2013; Kerlinger, 1979). In particular, this reliance helps the researcher explore the research questions and also serves as a prediction agent (Creswell, 2013). This study includes two types of theories: the main study theory and the underlying theories.

The purpose of employing the theoretical foundation is to support the aim of the present study. Mainly, the training transfer model (Baldwin \& Ford, 1988) and its literature are considered the main directive basis of this study's framework. Conversely, the underlying theories are used to partially explain the relation between the study variables. Those underlying theories are the "Social cognitive theory" (Bandura, 1997) and "Forgotten theory" (Ebbinghaus, 1964).

\section{Literature Review}

\subsection{Training Transfer}

Most scholars in the training transfer domain are deliberating over the precise definition of training transfer. In accordance with previous work in the training transfer domain (Al-Eisa et al., 2009; Barling, Weber, \& Kelloway, 1996; Burke \& Saks, 2009; Dvir et al., 2002; Ford \& Weissbein, 1997; Kraiger, 2002; Theorell et al., 2001; Twitchell, Holton, \& Trott, 2000), this study considers the operational definition of training transfer as "the transfer and application of the trained knowledge, skills and attitude as a behaviour on the job".

Generally, training transfer, or the implementation of training in the work environment, is complex and problematic (Al-Eisa, Furayyan, \& Alhemoud, 2009; Baldwin \& Ford, 1988). Therefore, the transfer problem is considered a serious organizational concern for researchers and practitioners (Baldwin, Ford, \& Blume, 2017; Donovan, \& Fu, 2018; Werrlich, Nguyen, \& Notni, 2018). For instance, U.S. corporations spent $\$ 356$ billion in 2015 on training without improvements in corporate performance (Beer et al., 2016). Therefore, one of the main theoretical problems in training transfer is developing a rooted theory related to this domain (Bhatti \& Kaur, 2009). Thus, this study would contribute to the literature by theorizing the training transfer model.

Grossman and Salas (2011) noted that, although several authors had reviewed and summarized the extant literature (Baldwin, Ford, \& Blume, 2009; Blume et al., 2010; Burke \& Hutchins, 2007; Cheng \& Hampson, 2008; Cheng \& Ho, 1998; Merriam \& Leahy, 2005), their conclusions regarding the key components of transfer remained somewhat ambivalent. Clearly, inconsistent and ambivalent findings in the training transfer literature suggest that more effort is required to develop a comprehensive training transfer theory.

To aid in the general investigation of training transfer, this variable was added to the present conceptual model of this study. 


\subsection{Training Design}

Training design can be defined as "the level to which (i) training has been designed and delivered to give trainees the capability of transferring learning to the job, and (ii) training instructions match job requirements" (Holton et al., 2000).

Training design has a large and dominant influence on the training transfer process (Gyimah, 2015; Nikandrou, Brinia, \& Bereri, 2009). Additionally, Bell, Tannenbaum, Ford, Noe, and Kraiger (2017) found that training design is one of the main themes of the training transfer domain. Training design is considered the basis for improving trainees' competencies on the job (Bhatti et al., 2013). Velada, Caetano, Michel, Lyons, and Kavanagh (2007) found that training design was significantly correlated with transfer. Furthermore, training design is considered, among all transfer models, as an important antecedent of transfer (Baldwin \& Ford, 1988; Burke \& Hutchins, 2007; Ford \& Weissbein, 1997). Indeed, it is stated that training design strategies represented $46 \%$ of trainers' reported best practices for influencing transfer (Saks \& Burke-Smalley, 2014). Indeed, if instrumental methods are described as best practice methods, then those methods significantly promote training transfer (Bhatti et al., 2013; Burke \& Hutchins, 2007; Grossman \& Salas, 2011).

Recently, Baldwin et al. (2017) reported that more confirmation related to training design and the implementations of training initiatives is required. Likewise, Bell et al. (2017) emphasized that more effort is necessary for investigating training design.

Training design in general and training techniques in particular show important and strong relationships with training transfer (Ford \& Weissbein, 1997; Grossman \& Salas, 2011; Gyimah, 2015; Nikandrou et al., 2009), which suggests that transfer design should be investigated further (Baldwin et al., 2017; Bhatti et al., 2013). Furthermore, Nikandrou, Brinia, and Bereri (2009) indicated that studies have seldom examined the impact of training design and other mechanisms (methods of design) on actual training transfer. Consequently, this study tested the following hypothesis:

H1: Training design has a positive influence on training transfer.

\subsection{Training Design and Memory}

This section aims to justify, describe, and review the relation between training design and training retention, i.e., how does training design preserve training memory? The purpose of this review is to precisely understand and then suggest a hypothesis for this relation. Therefore, and as mentioned before, relying on training design as a general term may be confusing. Practically, explaining design techniques instead of the general term (training design) would make the explanations more precise and may produce new insights for future studies.

Training design features and mechanisms are the detailed aspects and elements of training design (Bhatti et al., 2013) and are significant concerns in the training transfer literature (Nikandrou et al., 2009). Furthermore, traditional education methods (techniques) fail to optimize long-term memory (Kerfoot, 2010). In general, training design features are the tangible instruments of training design; this is represented by several terms, such as mechanisms, methods, elements, strategies, and/or techniques (Baldwin \& Ford, 1988; Burke \& Hutchins, 2007; Lim \& Morris, 2006; Nikandrou et al., 2009; Smolen, Zhang, \& Byrne, 2016). For simplicity, this study uses the term "techniques" instead of using several other terms.

It is argued that training professionals can use certain techniques in training design to increase training transfer in the workplace (Curado, Henriques, \& Ribeiro, 2015; Smolen et al., 2016). Therefore, many researchers have noted several types of training techniques (Baldwin \& Ford, 1988; Burke \& Hutchins, 2007; Grossman \& Salas, 2011). For instance, Baldwin and Ford (1988) highlighted the following techniques: conditions of transfer (e.g., over-learning), general principles (teaching the general rules), identical elements (having identical stimulus and response elements in training and transfer settings), and stimulus variability (using a variety of training stimuli). Additionally, Burke and Hutchins (2007) categorized training techniques by several features, e.g., by identification of learning needs, learning goals, content relevance, prominent instructional strategies and methods, self-management strategies, and/or instructional media.

Other examples of training design techniques are behavioural modelling, error management (error training), and realistic training environments, all of which have shown strong relationships with training transfer (Ford \& Weissbein, 1997; Grossman \& Salas, 2011).

The spacing effect and overlearning are remarkable techniques that can clarify the importance of training design for training retention. The spacing effect is a highly-valued technique that is used in several specializations (Bandura, 1989; Deffenbacher et al., 2008; Driskell, Willis, \& Copper, 1992; Ebbinghaus, 1964; Jaber, 2006; Ritter et al., 2011). Moreover, the spacing effect has many synonyms, such as retention interval (Driskell et al., 
1992). The spacing effect is described as the rehearsal of the training content at specific intervals (Ebbinghaus, 1964; Ritter et al., 2011) in order to increase the recall rate of the new information learned from the training programme (Jaber, 2006). Therefore, the overlearning technique is an approach that represents the repetition of practices to retain employee competencies (Ritter et al., 2011). As a method, the greater the degree of overlearning is, the greater its effect on memorizing knowledge and skills (Nijman, Nijhof, Wognum, \& Veldkamp, 2006).

Generally, it is obvious that training design has a fundamental role in promoting training retention via its techniques. In addition, training techniques provide a clear representation of training design.

Furthermore, this study draws a new logical diagram that explains how training design could preserve training memory with the consideration of time (Figure 1). As stated by Ebbinghaus, time is the main construct that affects memory. Therefore, well-designed training programmes are more successful in improving the trainees' retention (Martin, 2010). Therefore, a weak training design will delay the application of the training post-period, which will ultimately lead to low training retention. A suitable, timely plan (design) may be invested in the post-period of the training or after a short period of applying the training programme. Accordingly, the most focal means to explain that relation between training design and training retention is to compare strong and weak designs and their effects on retention (remembering) over time. In conclusion, the design that concentrates on the means that cause remembering could increase the rate of retention.

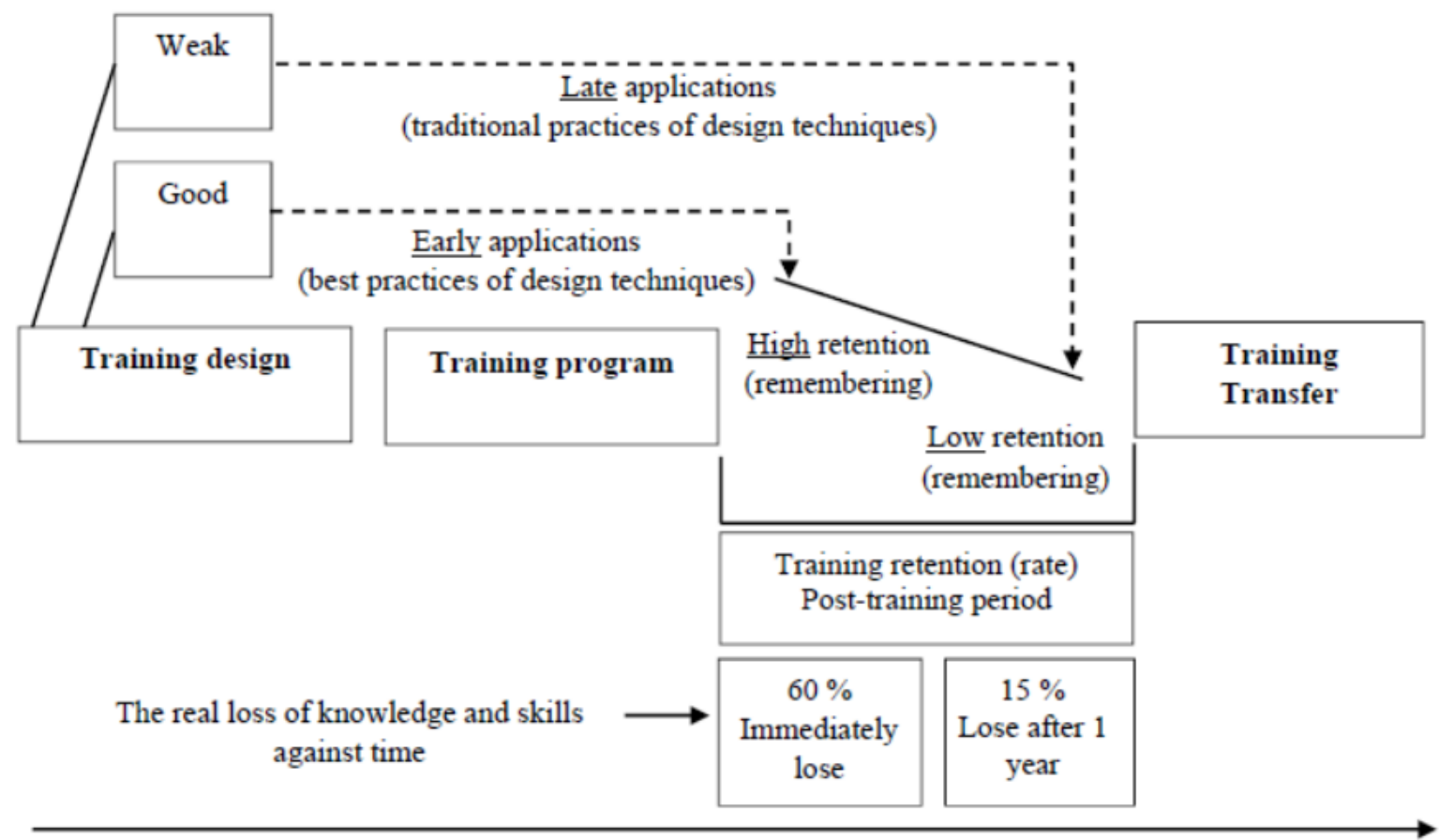

Figure 1. A Logical Discrimination between Weak and Good Training Designs Affecting Training Retention. The rates of retention are adopted from Wexley and Latham (2002)

Bhatti et al. (2013) noted that training design may influence training retention or help trainees to retain the learned skills. It is noteworthy that Velada et al. (2007) were the only researchers in the domain of training transfer who empirically studied the relation between training design and training retention; however, the relation between training design and training retention was not the main concern of Velada et al. (2007) or Bhatti et al. (2013).

Finally, most researchers provided reasonable perspectives of the relation between training design and training retention; however, few studies had applied any empirical investigation specifically in the domain of training transfer.

In accordance with the previous review, the following hypothesis was examined in this study:

$\mathrm{H} 2$ : Training design has a positive influence on training retention. 


\subsection{Training Retention and Training Transfer}

Training retention represents the retention of information, knowledge, or skills that were are obtained from training (Velada et al., 2007). Training retention is mainly associated with the memory (remembering) of the training content (Deffenbacher et al., 2008; Ong \& Tasir, 2015; Sakul-Thanasakdi, 2001; Velada et al., 2007).

Basically, the importance of retention has emerged because memory is a synonym of behaviour. For this, the weakening of behaviour is a consequence of forgetting (Donahoe \& Palmer, 1994; Pierce \& Cheney, 2013). Thus, memory is a central topic to behaviour science (Fryling \& Hayes, 2010). Similarly, May and Kahnweiler (2000) suggested that the lack of training retention could lead to inadequate training transfer. Overall, training retention (memory) has an obvious interaction with training transfer (behaviour).

Additionally, the domain of memory research has been applied in both laboratories and organizational (field) studies; however, one of the problems in studying skill retention and memory is that cognitive abilities have been found to be more important in laboratory studies than in field contexts or within organizational settings (Baldwin \& Ford, 1988; Blume et al., 2010). Therefore, increasing the number of organizational studies in the domain of memory (training retention) is suggested, instead of restricting such studies to laboratory experiments.

In the domain of training transfer, a few recent studies examined relation between training retention and training transfer (see, for example, Iqbal \& Dastgeer, 2017; Govaerts, Kyndt, \& Dochy, 2018). Bhatti et al. (2013) noted that few researchers included training retention in the training transfer theory. Similarly, Bhatti and Kaur (2009) indicated that studying training retention in the training and development (T\&D) field has inherent limitations.

Therefore, training retention was considered a mediator in this study. Baldwin and Ford (1988) also considered it a mediator in their transfer model. Furthermore, the mediating role of training retention is to be expected when, as reported by Bhatti et al. (2013), the training design has an indirect effect on training transfer.

According to the training retention literature, the following hypotheses were tested in this study:

H3: Training retention has a positive influence on training transfer.

H4: Training design has an influence on training transfer that is mediated by training retention.

\section{Proposed Study Model}

The proposed study model is primarily based upon the main training transfer model (Baldwin \& Ford, 1988), as well as the supporting theories. Then, the proposed model was modified according to the theoretical gaps noted in our literature review. Accordingly, the following model is recommended (Figure 2):

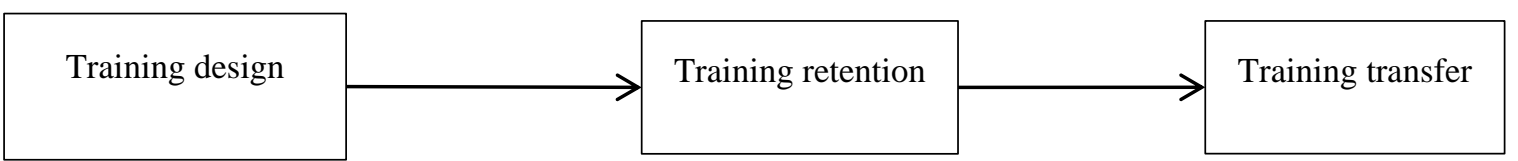

Figure 2. Conceptual Model

\section{Methodology}

In this study, the study population is the federal ministries of the UAE. Six out of 17 basic ministries were selected for data collection. These six ministries represent a variety of important sectors (Ministry of Education, Ministry of Energy, Ministry of Finance, Ministry of Health and Prevention, Ministry of Interior, and Ministry of State for Federal National Council Affairs). A proportion (six ministries) of the total population was selected for the purpose of efficient data collection. Since the total population number is 52, 000, the statistically-necessary sample number was stated as 382 employees (Krejcie \& Morgan, 1970).

Each sampling method aims to maximize the representation of the study population (Salkind, 2012). All employees in the federal ministries are responsible for applying (transferring) the training to their jobs. Since all the elements in the population are considered and each element has an equal chance of being chosen as the subject, simple random sampling was used in this study (Sekaran \& Bougie, 2013).

The unit of analysis in this study, nominated as an individual unit, is the employee in one of the federal ministries. The behavioural nature (transfer behaviour) of the study variable led the researchers to choose the employee as the unit of analysis. Sekaran and Bougie (2013) gave an example of choosing the individual level by considering the nature of the research variables, e.g., motivation. The individual nature (trainee memory) also advocates for studying the individual unit. Additionally, the individual level is common in the training transfer domain (Bhatti et al., 2013; Cheng \& Hampson, 2015; Holton et al., 2000; Velada et al., 2009).

This study is a cross-sectional data collection that collected data at a point in time. This study aims to study the 
relationships between variables against changes in specific situations (or indicators) through different points of time. This study is intended to take a general feature of the training transfer training phenomenon, in a very general format, linked to the federal ministries for a general period of time. For all these reasons, cross-sectional data collection was selected.

\subsection{Research Questionnaire}

Operationalization of the study variables was referred from the main resources in the training transfer domain (Table 1). Operationalization is utilized to ensure that the study items are accurate.

In particular, training retention identification is related to a specific concept in the process of training transfer. Referring to psychology, "retention" is mainly associated with memory (Deffenbacher, Bornstein, McGorty, \& Penrod, 2008; Ong \& Tasir, 2015; Sakul-Thanasakdi, 2001). Particularly, retention in the domain of training transfer is traditionally related to remembering or is considered a cognition attribute that represents the degree to which the trainee remembers the training (Velada et al., 2007).

The study questionnaire consisted of two sections: (i) demographic information and (ii) study items (questions). The questionnaire used a five-point Likert scale with the following responses: strongly disagree $=1$, disagree $=2$, neutral $=3$, agree $=4$, and strongly agree $=5$. The study items were founded from the dependable key resources shown in Table 1.

The work of Holton et al. (2000) is widely regarded as a major contribution to the identification of training design in the training transfer field (Bates et al., 2007, 2012; Khasawneh et al., 2006; Velada et al., 2007); hence, Holton et al.'s (2000) identification of training design is used in this study.

\subsection{Modification of Study Items}

Three stages of the study modification were applied: (i) back-translation, (iii) pre-test, and (iii) pilot test. Since our items were initially expressed in the English language, back-translation was applied to ensure a precise translation into Arabic. Backward translation was implemented according to the methods of Brislin $(1970,1986)$ and Banville et al. (2000). Therefore, a pre-test was performed, following the method of Sekaran and Bougie (2013). Sekaran and Bougie described pre-testing as the use of a small number of respondents (focus group) to test the appropriateness of questions and their comprehension. A group of five participants had modified the questionnaire items to suit the real study population participants. Following the pre-test, a pilot test was performed. The pilot test's purpose is to test the items' reliability (consistency) (Piaw, 2012). Accordingly, the study items achieved a reliable result (Cronbach's alphas $>0.7$ ) and then the modified study items were ready to be used with the target population.

Table 1. Operational definitions and study items

\begin{tabular}{|c|c|c|c|c|}
\hline Variable & Operational definition & Reference & $\begin{array}{l}\text { No. of } \\
\text { items }\end{array}$ & Reference \\
\hline $\begin{array}{l}\text { Training } \\
\text { Retention }\end{array}$ & $\begin{array}{l}\text { The degree to which the trainee } \\
\text { retains the content after } \\
\text { training is completed. }\end{array}$ & Velada et al., 2007 & 4 & $\begin{array}{l}\text { Velada et al., } \\
\quad 2007\end{array}$ \\
\hline $\begin{array}{l}\text { Training } \\
\text { Design }\end{array}$ & $\begin{array}{l}\text { The extent to which training is } \\
\text { designed and delivered in a } \\
\text { manner that enables trainees to } \\
\text { transfer learning to their job. }\end{array}$ & $\begin{array}{l}\text { Holton et al., 2000; Bhatti et } \\
\text { al., 2013. }\end{array}$ & 4 & $\begin{array}{l}\text { Holton et al., } \\
\quad 2000 .\end{array}$ \\
\hline $\begin{array}{l}\text { Training } \\
\text { Transfer }\end{array}$ & $\begin{array}{l}\text { Transfer and application of } \\
\text { knowledge, skills and attitude } \\
\text { as workplace behaviour. }\end{array}$ & $\begin{array}{l}\text { Ford and Weissbein, 1997; } \\
\text { Kraiger, 2002; Al-Eisa et al., } \\
\text { 2009; Burke and Saks, } 2009 .\end{array}$ & 6 & $\begin{array}{l}\text { Tesluk, Farr, } \\
\text { Mathieu, and } \\
\text { Vance, 1995; } \\
\text { Xiao, 1996. }\end{array}$ \\
\hline
\end{tabular}

\subsection{Data Collection and Statistical Techniques}

The study questionnaires were accompanied by an explanatory introduction, and the questionnaires were sent to all employees in the specified federal ministries. Questionnaires were sent via email to the employees' work email addresses. A total of 552 respondents completed and returned questionnaires. Incorrectly completed questionnaires and respondents who had not enrolled in any training in the past year were excluded, leaving 444 valid questionnaires (Table 2). Furthermore, the participant number (444 employees) exceeded the statistical requirements (382 employees). Schumacker and Lomax (2016, p. 47), stated that a sample size of 100-150 is sufficient for testing small models with well-behaved data. 
Table 2. General information on the response rate.

$\begin{array}{lc}\text { Total Number of Distributed Questionnaires } & 44,527 \\ \text { Total Number of Received Questionnaires } & 552 \\ \text { Response rate (\%) } & 1.2 \\ \text { Number of Excluded Questionnaires (Abnormal Filling) } & 108 \\ \text { Final Number of Questionnaires For Analysis (After Cleaning) } & 444 \\ \text { Sample Size Required } & 382 \\ \text { Actual Sample Size as \% of Required } & 116.2\end{array}$

In order to test our hypotheses, which included a mediating role, the researchers analysed the study results using partial least squares structural equation modelling (PLS-SEM) (Hair, Celsi, Money, Samouel, \& Page, 2016; Hair Jr, Hult, Ringle, \& Sarstedt, 2017); this analysis was performed using SmartPls software (Hair et al., 2017).

To get a precise result, a non-response bias assessment was conducted. The study data were collected for a period of approximately three months. Data were split into two groups: the early and late groups. The resulting analysis (after applying PLS-MGA) showed non-significant differences between the early group and the late group. Thus, the study was considered to have acceptable (stable) reliability.

\section{Results}

\subsection{Descriptive Statistics}

The descriptive statistics showed a diverse set of employees, which represents a generalizable population sample (Table 3).

All data were tested after ensuring that discriminant validity had been established. Discriminant validity is a statistical test that ensures that questionnaire items from different variables are distinct and do not correlate to each other (Hair et al., 2016). We performed a discriminant validity analysis (Fornell-Larcker criterion, cross-loading) in order to eliminate inappropriate items. The recommendations of Hair et al. (2017) relating to discriminant validity were applied. According to the discriminant validity test, one item out of 14 items was eliminated; this eliminated item was related the training design variable.

Table 3. Morphological Information and Respondents' Profiles $(n=444)$

\begin{tabular}{cc}
\hline Profile type & Details \\
\hline Study population No. & 52 thousand employees \\
\hline Supervisory role employee (\%) & 51.3 \\
Subordinate employee (\%) & 48.7 \\
\hline Training course attendance (\%) & 93.2 \\
\hline Secondary level (\%) & 7.5 \\
Diploma (\%) & 11.0 \\
Bachelor's (\%) & 57.0 \\
Master's (\%) & 17.4 \\
PhD (\%) & 7.2 \\
\hline Administrative job (\%) & 41.5 \\
A technical (specialized) job (\%) & 25.8 \\
Administrative and technical job (\%) & 19.0 \\
Administrative and field job (\%) & 10.7 \\
A field job (\%) & 3.0 \\
\hline Male (\%) & 33.5 \\
\hline Female (\%) & 66.5 \\
\hline Mean experience (years) & $15.4($ Max=40, Min=1) \\
\hline Mean age (years) & $45.6($ Max=67, Min=19) \\
\hline
\end{tabular}




\subsection{Correlation, Reliability, and Hypothesis Testing}

All items had acceptable reliability (Cronbach's alpha > 0.70). Also, all the hypotheses were accepted (H1, H2, $\mathrm{H} 3$, and H4) (Table 4). In general, all correlational effects were high, except the relation between training retention and training transfer $(0.143)$.

The fourth hypothesis (H4) represents the mediating effect of training retention on the relationship between training design and training transfer. According to bootstrapping analysis, the mediating role of training retention had a total effect of 0.089 and a significant result $(p=0.001$, T statistic $=3.242$, confidence intervals bias corrected: $5.00 \%=0.044$ and $95.00 \%=0.135$ ). The data analysis also showed that training design has an indirect effect on training transfer.

Table 4. Descriptive statistics, correlations, and reliabilities of variables

\begin{tabular}{cccccc}
\hline Variable & Mean & SD & Training Design & Training Retention & Training Transfer \\
\hline Training Design & 3.36 & 1.07 & $(0.93)$ & & \\
Training Retention & 3.65 & 0.99 & $0.618^{*}$ & $(0.947)$ & \\
Training Transfer & 3.54 & 1.08 & $0.839^{*}$ & $0.143^{*}$ & $(0.931)$ \\
\hline
\end{tabular}

Note: $* p$-values $<0.05 ; \alpha$ values (reliability) shown in parentheses

\section{Discussion}

All the hypotheses were accepted, though with different correlational effects. Training design had a significant (positive) influence on training transfer, with a high correlational (indirect) effect (0.839). This significant result is confirmed by other studies (Baldwin \& Ford, 1988; Burke \& Hutchins, 2007; Ford \& Weissbein, 1997; Velada et al., 2007).

Training design had a significant (positive) influence on training retention, with a high correlational effect (0.618); however, Velada et al. (2007) reported an insignificant relation result. This contrast may be due to cultural and institutional differences. The present study was applied in a governmental sector, whereas Velada et al.'s study was applied in a private entity (grocery organization). It has been noted that there are significant cultural differences between regions around the world (Hofstede \& Hofstede, 2005), which would influence employees' personal traits and organizational practices and cultures (Abdullah, 1992; Hassi \& Storti, 2011; Pattni \& Soutar, 2009; Rogers \& Spitzmueller, 2009).

The relation between training design and training retention gained central importance in the present study, as represented by the study title, "Does training design preserve training memory?" According to the study empirical result (Table 4), training design effectively preserves training memory. Training design techniques significantly influence whether the participants remember (retain) the knowledge and skills gained from the training programme.

In addition, training retention has a significant (positive) influence on training transfer, but a low correlation effect (0.143). Iqbal and Dastgeer (2017) and Velada et al. (2007) reported similar results, i.e., both studies reported significant correlations between training retention and training transfer with low total effects $(0.227$ and 0.33, respectively). Additionally, Govaerts, Kyndt, and Dochy (2018) reported that training retention has a significant effect on training transfer. Although many studies in psychology showed that memory has a considerable influence on behaviour (Donahoe \& Palmer, 1994; Pierce \& Cheney, 2013), the present study and other studies in the domain of training transfer (Iqbal \& Dastgeer, 2017; Velada et al., 2007; Govaerts et al., 2018) imply that memory is less important. This study showed that training retention is a secondary contributor of transferring training.

The most crucial reason for the differences between the study's results in the domain of training transfer and psychology is due to the differences in research methodologies. The present study used a subjective methodology (questionnaire), whereas in psychology, the objective approach is dominant (experiments). Baldwin and Ford (1988) mentioned that, in psychology, the research is concentrated in laboratory settings rather than organizational settings. Also, studying memory in some cases focuses on the newly learned knowledge (see, for instance, Bandura, 1997; Ebbinghaus, 1964). Thus, the training courses in this study may be a sequence of repeated courses in some form, which leads to the low observed effect of training retention toward training transfer. 


\section{Managerial Implications}

The training design remains the effective agent and dominant influencer of the training transfer process. Therefore, human resource departments and their supervisors must be highly qualified in designing training.

Training design also has a clear impact on maintaining training memory, and so it is emphasized again to avoid applying traditional training techniques. Evidence-based training techniques, such as "spacing" and "overlearning" and many others, would reduce the significant memory losses of traditional training programs.

\section{Study Limitations}

Training design predicts (or explains) only 32\% (R-squared value of 0.32 ) of training retention. Hence, many variables affect training retention and further research is necessary to identify them. The present study domain is general (all federal employees); as such, it is advisable to conduct a similar study on a particular sector, for instance, a medical or educational field. Applying the study variable in a particular field would demonstrate new insights. The present study is limited to the public sector; applying the study variable in the private sector would be more valuable. This study does not distinguish between the different types of job skills. In general, skill types consist of motor skills (musculoskeletal system to perform behavioural activities), cognitive skills (thinking, idea generation, etc.), and personal skills (interacting with others) (Arthur et al., 2003). When examining memory, these skill types must be considered (Arthur et al., 1998; Salas, Milham, \& Bowers, 2003; Schmidt \& Bjork, 1992).

\section{Conclusion and Recommendations for Future Study Directions}

Billions of dollars are lost by low application of training. Fast declination of training memory may contribute this loss. Therefore, the present study examined how to reduce that loss by testing several hypotheses as part of generating a conceptual model. Accordingly, this study demonstrates the significant relation between training design and training transfer. Training design is a dominant influencer of the training transfer process. Excellent training design is the crucial agent of a successful organizational training program.

This study also demonstrated that training design is one of the main preservers of training memory. Thus, training retention via training design will increase the retention of the training memory for a long period and thereby lower training expenses. It is highly recommended that future research examine the influence of training design on memory preservation (training retention), specifically in the organizational context, and in several types of skills and sectors since the training retention variable is one of the most important variables in the training transfer domain and is a critical research limitation.

In addition, training retention plays a central mediating role in the transfer model. Furthermore, training memory is one of the precursors of transfer behaviour. Therefore, addressing group memory is considered a valuable future direction. For instance, enrolling a group of employees in a training programme would increase the training memory versus individual enrolment.

Generally, it is fundamentally recommended to apply several investigations related to the present study's conceptual model (variables).

\section{References}

Al-Eisa, A. S., Furayyan, M. A., \& Alhemoud, A. M. (2009). An empirical examination of the effects of selfefficacy, supervisor support and motivation to learn on transfer intention. Management Decision, 47, 1221-1244. https://doi.org/10.1108/00251740910984514

Arthur, W., Bennett, W., Edens, P. S., \& Bell, S. T. (2003). Effectiveness of training in organizations: A meta-analysis of design and evaluation features. Journal of Applied Psychology, 88, 234-245. https://doi.org/10.1037/0021-9010.88.2.234

Arthur Jr, W., Bennett Jr, W., Stanush, P. L., \& McNelly, T. L. (1998). Factors that influence skill decay and retention: A quantitative review and analysis. Human performance, 11(1), 57-101. https://doi.org/10.1207/s15327043hup1101_3

Baldwin, T. T., \& Ford, J. K. (1988). Transfer of training: A review and directions for future research. Personnel Psychology, 41, 63-105. https://doi.org/10.1111/j.1744-6570.1988.tb00632.x

Baldwin, T. T., Ford, J. K., \& Blume, B. D. (2009). Transfer of training 1988-2008: An updated review and agenda for future research. International Review of Industrial and Organizational Psychology, 24, 41-70. https://doi.org/10.1002/9780470745267.ch2

Baldwin, T. T., Kevin Ford, J., \& Blume, B. D. (2017). The state of transfer of training research: Moving toward 
more consumer-centric inquiry. Human Resource Development Quarterly, 28(1), 17-28. https://doi.org/10.1002/hrdq.21278

Bandura, A. (1989). Social cognitive theory. In R. Vasta (Ed), Annals of Child Development Vol. 6. Six Theories of Child Development (pp. 1-60). Greenwich, CT: JAI Press.

Bandura, A. (1997). Self-Efficacy: The Exercise of Control. New York, NY: Worth Publishers.

Banville, D., Desrosiers, P., \& Genet-Volet, Y. (2000). Translating questionnaires and inventories using a cross-cultural translation technique. Journal of Teaching in Physical Education, 19(3), 374-387. https://doi.org/10.1123/jtpe.19.3.374

Barling, J., Weber, T., \& Kelloway, E. K. (1996). Effects of transformational leadership training on attitudinal and financial outcomes: A field experiment. Journal of Applied Psychology, 81, 827-832. https://doi.org/10.1037/0021-9010.81.6.827

Bates, R., Kauffeld, S., \& Holton III, E. F. (2007). Examining the factor structure and predictive ability of the German-version of the Learning Transfer Systems Inventory. Journal of European Industrial Training, 31(3), 195-211. https://doi.org/10.1108/03090590710739278

Beer, M., Finnström, M., \& Schrader, D. (2016). Why leadership training fails - and what to do about it. Harvard Business Review, 94(10), 50-57.

Bell, B. S., Tannenbaum, S. I., Ford, J. K., Noe, R. A., \& Kraiger, K. (2017). 100 years of training and development research: What we know and where we should go. Journal of Applied Psychology, 102(3), 305. https://doi.org/10.1037/apl0000142

Bhatti, M. A., \& Kaur, S. (2009). The role of individual and training design factors on training transfer. Journal of European Industrial Training, 34, 656-672. https://doi.org/10.1108/03090591011070770

Bhatti, M. A., Kaur, S., \& Battour, M. M. (2013). Training transfer and transfer motivation in the Malaysian banking sector. Global Business \& Organizational Excellence, 33, 40-57. https://doi.org/10.1002/joe.21522

Blume, B. D., Ford, J. K., Baldwin, T. T., \& Huang, J. L. (2010). Transfer of training: A meta-analytic review. Journal of Management, 36, 1065-1105. https://doi.org/10.1177/0149206309352880

Brislin, R. W. (1970). Back-translation for cross-cultural research. Journal of Cross-Cultural Psychology, 1(3), 185-216. https://doi.org/10.1177/135910457000100301

Bryman, A., \& Bell, E. (2011). Business Study Methods. Oxford, UK: Oxford University Press.

Burke, L. A., \& Hutchins, H. M. (2007). Training transfer: An integrative literature review. Human Resource Development Review, 6, 263-296. https://doi.org/10.1177/1534484307303035

Burke, L. A., \& Saks, A. M. (2009). Accountability in training transfer: Adapting schlenker's model of responsibility to a persistent but solvable problem. Human Resource Development Review, 8, 382-402. https://doi.org/10.1177/1534484309336732

Cheng, E. W., Sanders, K., \& Hampson, I. (2015). An intention-based model of transfer of training. Management Research Review, 38(8), 908-928. https://doi.org/10.1108/MRR-05-2014-0107

Cheng, E. W. L., \& Hampson, I. (2008). Transfer of training: A review and new insights. International Journal of Management Reviews, 10, 327-341. https://doi.org/10.1111/j.1468-2370.2007.00230.x

Cheng, E. W. L., \& Ho, D. C. K. (1998). The effects of some attitudinal and organizational factors on transfer outcome. Journal of Managerial Psychology, 13, 309-317. https://doi.org/10.1108/02683949810219873

Chartered Institute of Personnel and Development. (2015). Annual survey report 2015. London, England: Chartered Institute of Personnel and Development.

Creswell, J. W. (2013). Study Design: Qualitative, Quantitative, and Mixed Methods Approaches. Thousand Oaks, CA: Sage.

Curado, C., Henriques, P. L., \& Ribeiro, S. (2015). Voluntary or mandatory enrollment in training and the motivation to transfer training. International Journal of Training and Development, 19, 98-109. https://doi.org/10.1111/ijtd.12050

Custers, E. J. (2010). Long-term retention of basic science knowledge: A review study. Advances in Health Sciences Education, 15, 109-128. https://doi.org/10.1007/s10459-008-9101-y

Davis, L. E., Ajzen, I., Saunders, J., \& Williams, T. (2002). The decision of African American students to 
complete high school: An application of the theory of planned behavior. Journal of Educational Psychology, 94, 810-819. https://doi.org/10.1037/0022-0663.94.4.810

Deffenbacher, K. A., Bornstein, B. H., McGorty, E. K., \& Penrod, S. D. (2008). Forgetting the once-seen face: Estimating the strength of an eyewitness's memory representation. Journal of Experimental Psychology, 14, 139-150. https://doi.org/10.1037/1076-898X.14.2.139

Donahoe, J. W., \& Palmer, D. C. (1994). Learning and Complex Behavior. Boston, MA: Allyn \& Bacon.

Donovan, P., \& Fu, N. (2018). Bridging Research and Practice: Exploring the Key Factors for Training Transfer Among Practitioner. Academy of Management Proceedings, (1), 12391.

Driskell, J. E., Willis, R. P., \& Copper, C. (1992). Effect of overlearning on retention. Journal of Applied Psychology, 77, 615-622. https://doi.org/10.1037/0021-9010.77.5.615

Dvir, T., Eden, D., Avolio, B. J., \& Shamir, B. (2002). Impact of transformational leadership on follower development and performance: A field experiment. Academy of Management Journal, 45, 735-744. https://doi.org/10.5465/3069307

Ebbinghaus, H. (1964). Memory: A Contribution to Experimental Psychology. New York: Dover Publications.

Ford, J. K., \& Weissbein, D. A. (1997). Transfer of training: An updated review and analysis. Performance Improvement Quarterly, 10, 22-41. https://doi.org/10.1111/j.1937-8327.1997.tb00047.x

Ford, L. (2009). Improving training transfer. Industrial and Commercial Training, 41, 92-96. https://doi.org/10.1108/00197850910939135

Fryling, M. J., \& Hayes, L. J. (2010). An interbehavioral analysis of memory. European Journal of Behavior Analysis, 11, 53-68. https://doi.org/10.1080/15021149.2010.11434334

Georgenson, D. L. (1982). The problem of transfer calls for partnership. Training \& Development Journal, 36 , 75-78.

Govaerts, N., Kyndt, E., \& Dochy, F. (2018). The Influence of Specific Supervisor Support Types on Transfer of Training: Examining the Mediating Effect of Training Retention. Vocations and Learning, 11(2), 265-288. https://doi.org/10.1007/s12186-017-9190-y

Griffin, R. P. (2010). Means and ends: Effective training evaluation. Industrial and Commercial Training, 42, 220-225. https://doi.org/10.1108/00197851011048582

Grossman, R., \& Salas, E. (2011). The transfer of training: What really matters. International Journal of Training and Development, 15, 103-120. https://doi.org/10.1111/j.1468-2419.2011.00373.x

Gyimah, E. (2015). The Effect of Organizational Climate on Transfer of Training. European Journal of Business and Management, 7(19), 137-146.

Hair Jr, J. F., Hult, G. T. M., Ringle, C., \& Sarstedt, M. (2017). A Primer on Partial Least Squares Structural Equation Modeling (PLS-SEM) (2nd ed.). Los Angeles, CA: Sage.

Hair Jr, J. F., Celsi, M., Money, A. H., Samouel, P., \& Page, M. J. (2016). Essentials of business research methods (3rd ed). Armonk, NY: Routledge.

Holton, E. F. (1996). The flawed four-level evaluation model. Human Resource Development Quarterly, 7, 5-21. https://doi.org/10.1002/hrdq.3920070103

Holton, E. F. (2005). Holton's evaluation model: New evidence and construct elaborations. Advances in Developing Human Resources, 7, 37-54. https://doi.org/10.1177/1523422304272080

Holton, E. F., Bates, R. A., \& Ruona, W. E. A. (2000). Development of a generalized learning transfer system inventory. Human Resource Development Quarterly, 11, 333-360. https://doi.org/10.1002/1532-1096(20002 4)11:4<333::AID-HRDQ2>3.0.CO;2-P

Industry report 2000. (2000). Training, 37(10), 45-48.

Iqbal, K., \& Dastgeer, G. (2017). Impact of self-efficacy and retention on transfer of training: The mediating role of motivation to transfer. Journal of Management Development, 36(10), 1270-1282. https://doi.org/10.1108/JMD-06-2015-0087

Jaber, M. Y. (2006). Learning and forgetting models and their applications. In A. B. Badiru (Ed), Handbook of Industrial and Systems Engineering (pp. 1-30). Boca Raton, FL: CRC Press.

Jaber, M. Y., \& Sikström, S. (2004). A numerical comparison of three potential learning and forgetting models. 
International Journal of Production Economics, 92, 281-294. https://doi.org/10.1016/j.ijpe.2003.10.019

Kauffeld, S., \& Lehmann-Willenbrock, N. (2010). Sales training: Effects of spaced practice on training transfer. Journal of European Industrial Training, 34, 23-37. https://doi.org/10.1108/03090591011010299

Kavanagh, M. J. (1998). Transfer of training: A multi-stage model designed for practical use by organizations. In C. Scholz, \& J. Zentes (Eds.), Strategisches Euro-Management (pp. 301-321). Stuttgart, Germany: Schaffer-Poeschel.

Kerfoot, B. P. (2010). Adaptive spaced education improves learning efficiency: A randomized controlled trial. Journal of Urology, 183, 678-681. https://doi.org/10.1016/j.juro.2009.10.005

Kerlinger, F. N. (1979). Behavioral Study: A Conceptual Approach. New York, NY: Rinehart \& Winston.

Kim, J. H., \& Callahan, J. L. (2013). Finding the intersection of the learning organization and learning transfer. European Journal of Training and Development, 37, 183-200. https://doi.org/10.1108/03090591311301680

Khasawneh, S., Bates, R., \& Holton III, E. F. (2006). Construct validation of an Arabic version of the Learning Transfer System Inventory for use in Jordan. International Journal of Training and Development, 10(3), 180-194. https://doi.org/10.1111/j.1468-2419.2006.00253.x

Kim, J. W., Ritter, F. E., \& Koubek, R. J. (2013). An integrated theory for improved skill acquisition and retention in the three stages of learning. Theoretical Issues in Ergonomics Science, 14, 22-37. https://doi.org/10.1080/1464536X.2011.573008

Kraiger, K. (2002). Decision-based evaluation. In K. Kraiger (Ed.), Creating, Implementing, and Managing Effective Training and Development: State-of-the-Art Lessons for Practice (pp. 331-375). San Francisco, CA: Jossey-Bass.

Krejcie, R. V., \& Morgan, D. W. (1970). Determining sample size for research activities. Educational and psychological measurement, 30(3), 607-610. https://doi.org/10.1177/001316447003000308

Lim, D. H., \& Morris, M. L. (2006). Influence of trainee characteristics, instructional satisfaction, and organizational climate on perceived learning and training transfer. Human Resource Development Quarterly, 17, 85-115. https://doi.org/10.1002/hrdq.1162

May, G. L., \& Kahnweiler, W. M. (2000). The effect of a mastery practice design on learning and transfer in behavior modeling training. Personnel Psychology, 53, 353-373. https://doi.org/10.1111/j.1744-6570.2000.tb00205.x

McCracken, M., Brown, T. C., \& O'Kane, P. (2012). Swimming against the current: Understanding how a positive organisational training climate can enhance training participation and transfer in the public sector. International J. of Public Sector Management, 25, 301-316. https://doi.org/10.1108/09513551211244124

Merriam, S. B., \& Leahy, B. (2005). Learning transfer: A review of the research in adult education and training. PAACE Journal of lifelong learning, 14(1), 1-24.

Mozer, M. C., \& Lindsey, R. V. (2016). Predicting and improving memory retention: Psychological theory matters in the big data era. In M. Jones (Ed.), Big Data in Cognitive Science (pp. 34-64). New York, NY: Routledge.

Nijman, D. J. J. M., Nijhof, W. J., Wognum, A. A. M., \& Veldkamp, B. P. (2006). Exploring differential effects of supervisor support on transfer of training. Journal of European Industrial Training, 30, 529-549. https://doi.org/10.1108/03090590610704394

Nikandrou, I., Brinia, V., \& Bereri, E. (2009). Trainee perceptions of training transfer: An empirical analysis. Journal of European Industrial Training, 33, 255-270. https://doi.org/10.1108/03090590910950604

Ong, C. P., \& Tasir, Z. (2015). Self-instructional module based on cognitive load theory: A study on information retention among trainee teachers. Educational Technology Research and Development, 63, 499-515. https://doi.org/10.1007/s11423-015-9383-8

Piaw, C. Y. (2012). Mastering research methods. Malaysia: McGraw-Hill.

Pierce, W. D., \& Cheney, C. D. (2013). Behavior Analysis and Learning. New York, NY: Taylor \& Francis.

Ritter, F. E., Baxter, G. D., Kim, J. W., \& Srinivasmurthy, S. (2011). Learning and retention. In J. D. Lee, \& A. Kirlik (Eds.), The Oxford Handbook of Cognitive Engineering (pp. 1-31). New York, NY: Oxford.

Saks, A. M., \& Burke-Smalley, L. A. (2014). Is transfer of training related to firm performance? International 
Journal of Training and Development, 18, 104-115. https://doi.org/10.1111/ijtd.12029

Salas, E., Milham, L. M., \& Bowers, C. A. (2003). Training evaluation in the military: Misconceptions, opportunities, and challenges. Military $\quad$ Psychology, $\quad 15(1), \quad 3$. https://doi.org/10.1207/S15327876MP1501_01

Sakul-Thanasakdi, K. (2001). Applying Cognitive Load Theory to Second Language Acquisition (Unpublished Doctoral Thesis). University of New South Wales, Sydney, Australia.

Salkind, N. J. (2012). Exploring research (8th ed.). New Jersey: Person.

Schmidt, R. A., \& Bjork, R. A. (1992). New conceptualizations of practice: Common principles in three paradigms suggest new concepts for training. Psychological science, 3(4), 207-218. https://doi.org/10.1111/j.1467-9280.1992.tb00029.x

Sekaran, U., \& Bougie, R. (2013). Research Methods for Business: A Skill-Building Approach (6th ed.). West Sussex, England: John Wiley \& Sons.

Smolen, P., Zhang, Y., \& Byrne, J. H. (2016). The right time to learn: Mechanisms and optimization of spaced learning. Nature Reviews Neuroscience, 17(2), 77. https://doi.org/10.1038/nrn.2015.18

Simosi, M. (2012). The moderating role of self-efficacy in the organizational culture-training transfer relationship. International Journal of Training and Development, 16, 92-106. https://doi.org/10.1111/j.1468-2419.2011.00396.x

Taylor, P. J., Russ-Eft, D. F., \& Chan, D. W. L. (2005). A meta-analytic review of behavior modeling training. Journal of Applied Psychology, 90, 692-709. https://doi.org/10.1037/0021-9010.90.4.692

Tesluk, P. E., Farr, J. L., Mathieu, J. E., \& Vance, R. J. (1995). Generalization of employee involvement training to the job setting: Individual and situational effects. Personnel Psychology, 48(3), 607-632. https://doi.org/10.1111/j.1744-6570.1995.tb01773.X

Theorell, T., Emdad, R., Arnetz, B., \& Weingarten, A.-M. (2001). Employee effects of an educational program for managers at an insurance company. Psychosomatic Medicine, 63, 724-733. https://doi.org/10.1097/00006842-200109000-00004

Tracey, J. B., Tannenbaum, S. I., \& Kavanagh, M. J. (1995). Applying trained skills on the job: The importance of the work environment. Journal of Applied Psychology, 80, 239-252. https://doi.org/10.1037/0021-9010.80.2.239

Twitchell, S., Holton, E. F., \& Trott, J. W. (2000). Technical training evaluation practices in the United States. Performance Improvement Quarterly, 13, 84-109. https://doi.org/10.1111/j.1937-8327.2000.tb00177.x

Velada, R., Caetano, A., Bates, R., \& Holton, E. (2009). Learning transfer-validation of the learning transfer system inventory in Portugal. Journal of European Industrial Training, 33(7), 635-656. https://doi.org/10.1108/03090590910985390

Velada, R., Caetano, A., Michel, J. W., Lyons, B. D., \& Kavanagh, M. J. (2007). The effects of training design, individual characteristics and work environment on transfer of training. International Journal of Training and Development, 11, 282-294. https://doi.org/10.1111/j.1468-2419.2007.00286.x

Werrlich, S., Nguyen, P. A., \& Notni, G. (2018, June). Evaluating the training transfer of Head-Mounted Display based training for assembly tasks. Presented at the Proceedings of the 11th PErvasive Technologies Related to Assistive Environments Conference (pp. 297-302). ACM. https://doi.org/10.1145/3197768.3201564

Wexley, K. N., \& Latham, G. P. (2002). Developing and Training Human Resources in Organizations. Englewood Cliffs, NJ: Prentice Hall.

Xiao, J. (1996). The relationship between organizational factors and the transfer of training in the electronics industry in Shenzhen, China. Human Resource Development Quarterly, 7(1), 55-73. https://doi.org/10.1002/hrdq.3920070107

\section{Copyrights}

Copyright for this article is retained by the author(s), with first publication rights granted to the journal.

This is an open-access article distributed under the terms and conditions of the Creative Commons Attribution license (http://creativecommons.org/licenses/by/4.0/). 